\title{
Perspectives on Leadership in Times of Crisis
}

\section{Raluca Parjoleanu ${ }^{\star}$}

\begin{tabular}{l}
\hline \multicolumn{1}{c}{ A R T I C L E I N F O } \\
\hline Article history: \\
Accepted November 2020 \\
Available online December 2020 \\
\hline JEL Classification \\
M54 \\
Keywords: \\
Leadership; Pandemic; Crisis; \\
Vulnerability; Global \\
\end{tabular}

\begin{abstract}
A B S T R A C T
As research evolves, new leadership models are proposed and it is increasingly necessary to adapt leadership behaviors to the organisation in which they are exercised. Given the highly competitive sphere in which most organizations operate in the XXIst century, leaders, whether formal or informal, must develop leadership skills and abilities to lead the organization toward continuous and competitive development. The year 2020, with its many crises, has brought even more to the spotlight the crucial role of leaders in sustainability and paving the way for the success of organisations.
\end{abstract}

\section{Introduction}

As the workforce is changing over time, so is the nature of leadership. People in leadership roles face an extremely complicated context. Revolutionary technological changes, combined with economic challenges and the trend towards strategic alliances, have changed the processes, boundaries and structures of organisations. Delay, downsizing and outsourcing are common practices. Traditional bureaucratic organizations have not completely disappeared, but have merged with newer styles of more flexible organizations that allow for greater participation (Graetz and Smith, 2009), According to Ashkenas, Ulrich, Jick and Kerr (2002), such changes in processes, boundaries, and structure require a new set of leadership skills that emphasise shared leadership and the ability to "connect" people from different cultures and different nationalities. In an era of rapid change and expectations for greater employee participation, it is essential that leaders are able to remove barriers that may inhibit innovation and the sharing of power in different groups. Indeed, with more and more organisations relying on their leaders to provide them guidance needed to survive, understanding and expanding leadership research is remains vital.

\section{Literature review}

Trying to define the notion of leadership is not a simple task. "The term leadership is a word taken from the common vocabulary of the English language and incorporated into the technical vocabulary of some scientific disciplines, without being redefined precisely" (Yukl, 2006). This lead to the absence of a universally accepted definition of leadership. It was noted that scientists provide different definitions based on individual perceptions and on the parts that seem more important to them. Upon studying the literature on this topic, Stogdill (1974) made a judgement statement that "there are almost as many definitions of leadership as there are people who have tried to define the concept".

In Romanian, the term leadership is a neologism and was translated by "conducere" or, in most cases, adopted as it is.

Scientists have come up with countless definitions to leadership based on types of processes, influences, personality, configuration, certain behaviours, persuasiveness, power, achievement of objectives, making distinctions based on the role of interplay, or mergers of the above mentioned characteristics. (based on Bass, 1990, Northouse, 2001 and Yukl, 2006), The majority of the provided descriptions on leadership are based on the deduction this phenomenon entails a situation of social interplay with a clear intent to influence the others in order to get to a specific result. Unfortunately, most definitions are extremely different. Thus the attempts to describe leadership include contrasting views on who is employing the influence, the predetermined scope of the influence, the influence employment approach, or the result of this process. (Yukl, 2006).

Definitions have one thing in common: they refer to the process of influencing the achievement of common objectives and also highlight the inclination of people to come together in groups, the entire society 
being based on interrelationships. As a generic human action, leadership initiates and triggers the activities of an organisation, highlighting the volitional content of the human psyche.

Being perceived differently by different people, the study of leadership should be based on understanding the structure and functioning of the organisation as an open social system and the need of members to achieve a common objective.

All these factors have led researches to come up with different characterisations of leadership:

\section{Figure 1 - Some leadership characterisations by researchers}

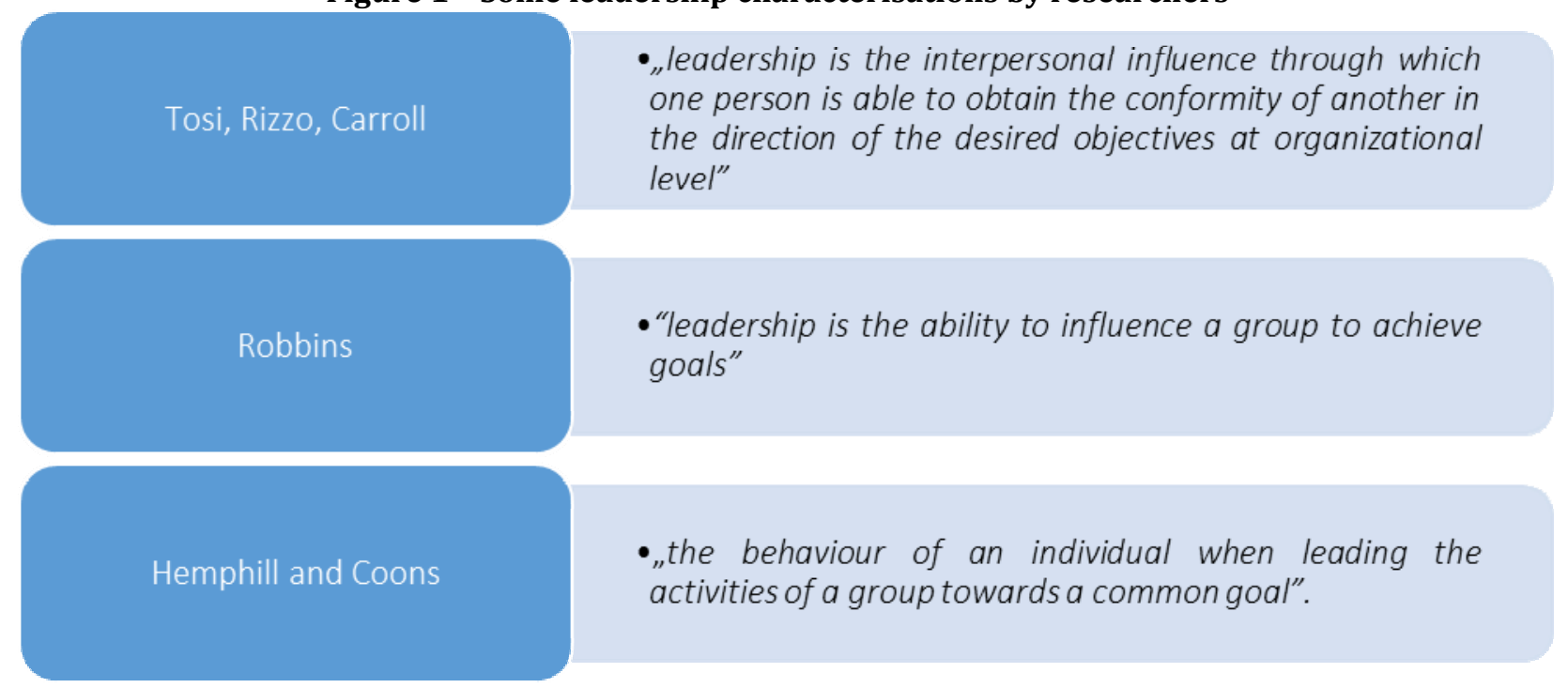

Source: literature graphic representation from Tossi, Rizzo, Carroll (1994), Robbins (2001) and Hemphill, Coons

\section{Leadership considerations}

After World War II, there was an unprecedented globalization of organisations, both private and public, that required leaders to work internationally in certain locations outside their home culture (expatriate leaders), often in s diverse set of different cultures. The growth of electronic communications and the World Wide Web, which took its first steps in 1991, has made it possible for multinational organizations to operate continuously on global projects, in all time zones and in many different cultures around the world. Traditionally, organization leaders had worked with people who looked like them, shared the same culture, and worked in the same geographical location. Today's leaders find themselves working in a very different landscape. Labour forces characterized by extreme homogeneity are an artefact of the past. With the change in social habits and the growth of the Internet and its ability to reach the globe, the modern environment requires people of all skin colours, backgrounds and values to work together in organizations. A challenge to today's reality is that while technology has brought us together, people still work with the same stereotypes and mind-sets that have divided groups throughout history. Thus, contemporary leadership requires the creation of direction, alignment and engagements with employees, who look, speak and act differently. (McCauley, Van Velsor, Ruderman, 2010), Leaders in this current environment need to engage and manage relationships between different employees, customers and suppliers around the world. In short, today's leader must encourage cooperation across a wide range of geographical, demographic and functional boundaries in order to succeed. (Ernst and Chrobot-Mason, 2011),

The vast majority of leadership research has addressed the question: What is effective leadership? Traditionally, leadership was thought of as a position in a hierarchical organisation held by a manager or supervisor with established responsibilities, authorities, and limits of influence. For many years, the field has answered the question of effective leadership by analysing the characteristics of a leader, either naturally in bureaucrats or more systematically in laboratories. According to McCauley (2010), the answers to that question took the form of personal attributes (e.g., personality and intelligence), roles and behaviours used by leaders, skills that distinguish best leaders from others, expertise (e.g., tacit knowledge) and mastery of challenging experiences.

Analysing many definitions of leadership, McCauley (2010) points out that those traditional approaches to leadership have three things in common, as it is shown in Figure 2: 


\section{Figure 2 - Characteristics of traditional leadership approaches}

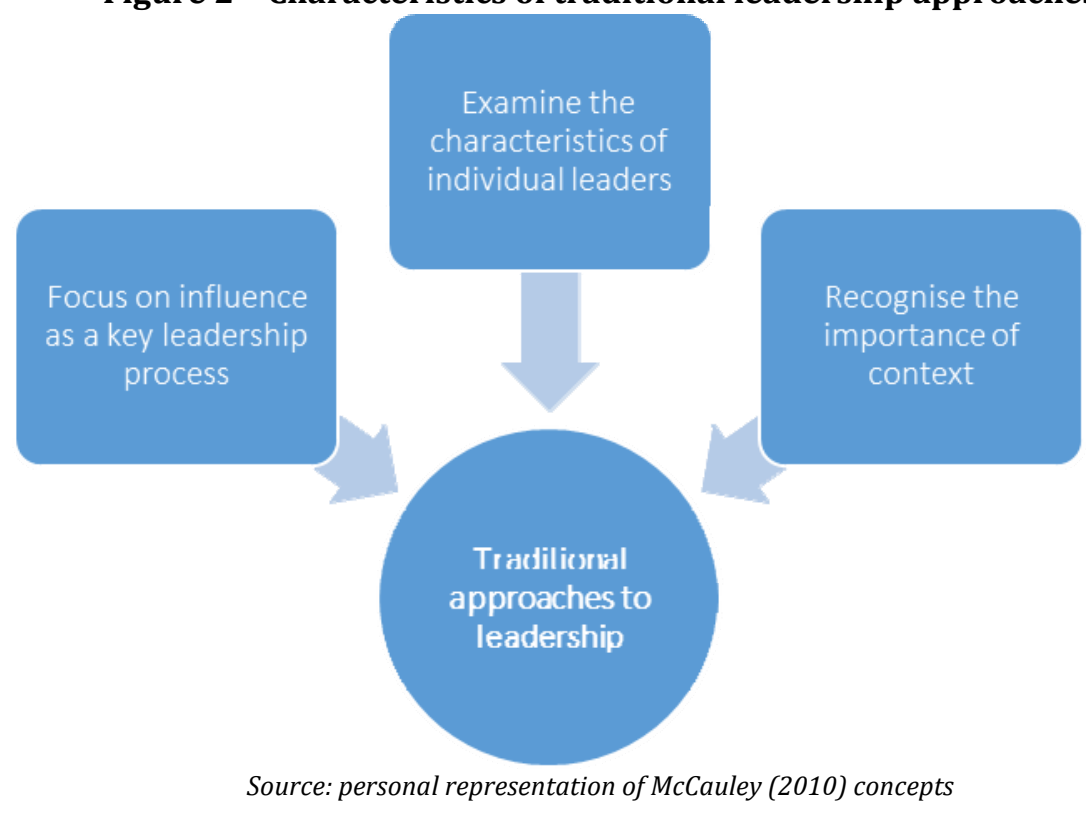

These models tend to emphasize the relationship between an organizational leader and his followers. McCauley also notes that these traditional models have common pitfalls that they have recently discussed. These pitfalls are presented in figure 3:

Figure 3 - Common pitfalls of traditional leadership models

(1) an overburdening of the individual to the detriment of

organizational processes

(2) the confusion of positional authority with influence,

(3) the expectation that a single individual has all the necessary

capabilities

(4) ignoring the particular requirements of different situations such

as the heterogeneity of the workforce.

Source: personal representation of McCauley (2010) concepts

More recently, there has been a trend away from this positional approach to leadership, with an emphasis on leader characteristics toward a more modern approach that holds that leadership is a common phenomenon built between people. (DeRue and Ashford, 2010; Pearce and Conger, 2003). The concept of common leadership means that there is a social process of group interaction and the development of a common understanding of the organisation's goals and vision. As such, leadership requires social interactions that allow a team to work. Thus Boal and Hooijberg (2000) argue that leadership belongs to the organisation and not to the people. At a fundamental level, leadership can be understood as the social process of generating the direction, alignment and commitment necessary for a group to achieve collective goals. (Drath and colab., 2008; McCauley et al., 2010). It is related to leadership functions that encompass the actions of many people, processes, structures and practices. Also, leadership must not appear within the limits of a formal hierarchy; it can happen anywhere, anytime and is not limited to a certain setting. Over the years, the field has evolved from a focus on the individual to a focus on the actions of a team. Leadership is now thought of as a relational property and not as an individual ability. The field now concerns leadership embodied among people, rather than a function located in a single individual, with the authority granted by a bureaucracy to lead a certain group. 
As organisations increasingly confront global markets and operate across national borders, career paths are becoming increasingly international, and management tasks are most likely to involve leadership in multicultural contexts. In this regard, leaders face multiple new challenges, namely, culturally diverse teams that they need to lead, that they need to evaluate need to be managed, people need to be diagnosed for their potential for international leadership, training programs need to be created in which managers can benefit from systematic education on intercultural leadership (Schyns, Kiefer, Kerschreiter and Tymon, 2011) and in the case of intercultural enterprises, the cultural difference between partners must be recognised (Javidan, Stahl, Brodbeck and Wilderom, 2005),

In order to successfully manage multinational teams and projects, leaders benefit greatly from training and education programs, in which relevant cultural knowledge is transferred and intercultural skills are developed (Bass, 2008). Black and Mendenhall (1990) showed the overall effectiveness of intercultural training programs. Programs for equipping managers for international projects and missions should include general and culture-specific information, which, for example, could be derived from the comparative study of 61 GLOBE nations. (House and colleagues, 2004) and in-depth studies of 25 companies (Chhokar et al., 2007) and can start with a solid diagnosis of one's leadership style. $360^{\circ}$ leadership feedback tools could be built on empirically established intercultural leadership dimensions (Ruderman and colleagues, 2011), They can provide leaders with feedback on their and others' expectations and perceptions of leadership in intercultural and global contexts, thus supporting the understanding of the extent to which "leadership is in the eye of the beholder" and the role of congruent cultural leadership with almost universal attributes.

Companies should recruit employees based on their international leadership potential. Spreitzer, McCall and Mahoney (1997) developed a "Prospector" tool that allows the early identification of international directors. The tool includes 14 dimensions (eg, sensitive to cultural differences, business knowledge, courage to take a stand, bring out the best in people, act with integrity, be attentive, commit to success, take risks, use feedback, is culturally adventurous, seeks opportunities to learn, is open to criticism, seeks feedback, is flexible), which measures the relevant competencies of individuals and the ability to learn from experience.

According to Beechler and Javidan (2007), the concept of "global mentality" can be another fruitful way to approach the selection of international leaders. The research of Gupta and Govindarajan (2002) and that of Levy (2005) have established that the global mentalities and cognitive abilities of senior managers are fundamental to organizational success in international environments. Integrating different research findings, Levy, Bechler, Taylor, and Boyacigiller (2007) suggested that a global mind-set consists of three components: openness to multiple spheres of meaning and action, differentiated articulation of cultural and strategic dynamics locally and globally, and integration in these spheres. Companies can use scales to measure global mind-sets in the evaluation procedures to filter out potential intercultural leaders (Javidan and Teagarden, 2011; Levy, 2005).

In addition, research on the cultural profiles of corporations and regional cultural groups can be helpful in planning and conducting international / multinational activities. Predictions of the success of joint partnerships were frequently built on an index that determined the cultural similarity between actors using the Hofstede dimensions (Kogut and Singh, 1988; Magnuson, Wilson, Zdravkovic, Zhou and Westjohn, 2008). The GLOBE project provides more recent and sophisticated profiles of the culture of society and cultural groups, which have been applied for the analysis of cultural factors of inhibition and improvement of intercultural mixed societies. (Javidan et al., 2005). Indices developed by Smith et al. (1996) in their event management activity reflect what sources of guidance they use in the management of work events and, therefore, are closely related to managerial contexts. In general, the culture-tightness dimension offered by Gelfand and colleagues (2011) provides an additional option to systematically compare cultures on reasons relevant to global economic and political conduct.

\section{Leadership and vulnerability}

It is necessary for the leaders nowadays to ask themselves existential questions that will help them orient their efforts on what really matters. When talking about leadership, being self-aware is an asset. Unfortunately, most leaders do not spend time to get to know the inner self. Leaders prefer to focus on the tasks at hand instead of reflecting on facts that can be really uncomfortable. Reflection might get leader to the realisation of past errors in action or judgement, might reflect a need for boundaries or might generate the conclusion that less micromanagement could be beneficial.

It is a lot easier to remain on routes that we already know. But growth and effectiveness of leaders is found in the situations when boundaries are pushed. It is vital for leaders to learn how to be self-aware and sincere with themselves. "Great leaders" are those that comprehend the idea that before any other characteristic, we are human, we have psychological needs and we tend to be insecure, vulnerable and sometimes irrational.

These leaders understand that they first need to know themselves and be self-aware, because this will lead to a better understanding of things. This is where personal growth and a process of continuous learning have to start. Leaders need to understand what motivates them and what sets them off, which are 
their strengths and weaknesses so that they can bring in the organisation people to complement their characteristics.

"Great leaders" accept that they need to be vulnerable in order to lead "with integrity, authenticity and responsibility of their organisations". Psychologist Brené Brown (2012) postulates that "vulnerability is the birthplace of innovation, creativity and change" and "courage begins by showing ourselves and letting ourselves be seen". Using Brown's vision will lead to building organisational cultures focused on growth of the individuals instead of seeking perfection.

Brené Brown (2012) also presents an excellent example of the power of vulnerability coming from corporate Monday. The reference is to the leadership approach adopted by Lululemon CEO Christine Day. Brown presents in his book how Christine Day transformed from the CEO who was always right into the best leader. Her transformation came when she realised that people do not dedicate themselves to their work because they are told, but if they are allowed to adopt the idea being guided by purpose and that the role of the leader is to create the necessary environment for them to manifest. Changing the CEO's approach is in fact moving from a controlling attitude to engaging in vulnerability to taking risks and cultivating trust. Although vulnerability can sometimes make us feel powerless, the change made by the CEO was an indisputable power move. The change in approach has had extremely beneficial consequences for the corporation, the number of stores has increased 2.5 times, total revenues have increased more than 3 times, and the value of the company's shares has increased more than 3 times since the Initial Public Offering.

The effectiveness of this approach is supported by other research. An article published in 2017 in the Harvard Business Review, "Bursting CEO Bubble", states that "as leaders move up in an organisation's hierarchy, there is a risk of becoming isolated from the information that they need to define the organisation's future." People fear to bring bad news to their severe leaders.

The HBR article quotes Nilekani, co-founder of the multinational corporation Infosys. Nilekani claims that "If you are a leader, you can put yourself in a cocoon of good news." The opposite happens in the case of leaders that want to innovate, as they "deliberately put themselves in situations where they may be unexpectedly wrong, unusually uncomfortable, and unusually silent."

Great leaders do not pretend to know everything and to be the beholder of all answers. They understand that creativity and solutions to complicated issues are born when employees work together. It's important for leaders to understand that creating an organisation in which employees feel safe to share honest points of view without being dismissed is essential and that these points of view can lead to the growth of the entire company.

\section{Leadership in times of crisis}

In 2020, the world was hit by the Covid-19 or SARS-CoV2 pandemic, as this virus was also called. Given the global spread of the crisis caused by this virus, it is a good opportunity to examine crisis leadership.

In times of crisis such as the present, companies are forced to test their ability to react and adapt, but at the same time the leadership skills of managers, which are even more important. In addition, for organisations it is at the same time an opportunity to test the most important values of employees such as: loyalty, involvement, commitment, commitment and, more than all, trust. But also, the confidence within the team and the team members' confidence in their leaders.

There has been a lot of talk about leadership in recent years, but this concept has translated into different values or rather a different hierarchy of priorities before the pandemic broke out. Rather, it had to do with the ability to support people to step out of their comfort zone to evolve continuously and perform on all levels. Instead, in the new context, it is much more important to support employees in adjusting to the new reality in terms of how they work but also to manage general uncertainty in order to achieve a balance in terms of mental health.

In the current period, full of uncertainties from all points of view, a leadership and management skill that can make a difference is related to quickly identifying the changes that are required, managing them in a short time to minimize the impact of negative events on the company and implicitly on the majority of employees. Then there will remain the ability to communicate objectively and in a clear way with the team but also to maintain a high level of positivism that will inspire courage for the team to overcome the crisis period in which we are already or will occur.

Leadership and the ability to provide a coherent vision for the company are all the more necessary given that most employees operate remotely during this period, a situation that will probably continue until the end of the year. This entails a series of challenges, among which the most demanding are the permanent communication with the employees, the way of following and sharing the tasks on the teams, but also the constant transmission of the situation in which the company is.

But one of the most important is how to keep all colleagues connected and engaged in the company's goals and mission, without face-to-face relationship. If before the employees of the companies talked face to face with their leaders, maybe even with the main leader of the company, which creates a state of security and trust through the existence of physical closeness, team spirit that is created including informal discussions during breaks or from lunch taken together, in the current context, all these things are missing. 
In their absence, the feeling of belonging to the team but also to the organizational culture can be lost, which can be an extremely important factor in motivating and involving employees.

Communication is essential in times of crisis. For this reason, frequent communication from leaders and managers with employees has become essential during this period, but it is a concise, objective, transparent communication about the actual situation and as optimistic as possible, as far as the general situation of the company allows, because both positive and negative exaggerations create an artificial context that can lead to loss of credibility, and hence loss of loyalty, commitment and employee involvement.

Equally important during a crisis is for leaders to be flexible in thinking in order to explore any type of opportunity and approach, sometimes even unconventional. They must be open enough to identify in unfavourable circumstances the possibilities that may arise beyond the obvious because often a crisis is a good opportunity to reinvent.

Hubert Joly, president and former CEO of Best Buy, publishes in May 2020 in the Harvard Business Review the article „Lead Your Team Into a Post-Pandemic World”. He spoke with many corporate CEOs and discussed their approaches. He notes two approaches of corporate leaders during this period. In a crisis with such proportions, organizations first approach is to focus on the necessities of their employees as human beings. It's important to remember the entire spectre of needs as Maslow has stated them. First of all, leaders need to tend of employees' need of security, but afterwards the needs from the top of the pyramid should not be omitted. People need them even more in times of crisis in order to maintain their sanity.

The second approach is related to the staging of actions to counteract the crisis. In general, these stages refer to: the housing phase, the reopening phase and the post Covid-19 phase. Joly recommends combining the two approaches for leaders to be able to be effective in managing their companies.

In the first part of the pandemic, organisations focused on protect the safety of their employees. They started using broadly the "work from home" system, contracted companies to do permanent disinfection in the buildings, in the cases where people couldn't work from home

After overcoming the safety stage, leaders have strived to ensure employees' financial security. They tried not to make stuff reductions even if this meant in some cases the imposition of holidays or technical unemployment and increased the salary for front-line workers. Some have set up employee support funds to meet urgent needs. In some companies, it was the executives and the board of directors who agreed to reduce their salaries; many offered solutions to employees who had people in care.

The way of keeping all colleagues connected and engaged in the company's objectives and mission, without the face-to-face relationship is very important. If before the employees of the companies talked face to face with their leaders, maybe even with the main leader of the company, which creates a state of security and trust through the existence of physical closeness, the team spirit that is created, including informal discussions during breaks or from lunch taken together, in the current context, all these things are missing. In their absence, the feeling of belonging to the team, but also to the organisational culture can be lost, which can be an extremely important factor in demotivating and losing employees.

Above the hierarchy of needs, leaders did their best to facilitate the networking and communication and to maintain the psychological health of employees. Leaders started to connect with their subordinates frequently, transparently and sincerely, using the most "personal" approaches possible, having videoconferences on online platforms (such as Zoom, Webex or Microsoft Teams), instead of just calls or emails, allowing flexible working hours, organising regular breaks or networking events and making themselves available for all employees. It is important to note that there are organisations that have made psychological health enhances available freely for their employees - such as counselling, online yoga and meditation gatherings, to support their workers to overcome these difficult times in a more balanced way.

In times of crisis, people tend to believe that the archetypal male leader is the one to pull people through difficult periods - a hero that is strong, self-confident, looking unerring and strong. Joly points out that this "would not be the best leadership model" in this situation. In this type of situation the best leadership approach is to combine great analytical and rational thinking with openness, vulnerability and compassion. To support this statement it is sufficient to note that several countries that seem to be going through the pandemic in the most effective way (let's take the examples of Denmark, Finland, Germany, Iceland, Norway or Sweden). A thing that all these states have in common is that are all led by women that appear to use both a scientific path, but also compassion and empathy.

Going back to the leaders of organisations, in the phase that we still are in, where everyone needs to take shelter, organisations should check if the steps they take are congruent to the organisational vision.

Figure 4 shows the measures that organisations should take in order to make sure that they satisfy the entire hierarchy of human needs of their employees. 
Figure 4 - Measures covering human needs that should be adopted in periods of crisis, like the Covid19 pandemic

Determining the requirements for bringing people back into the office, taking into account the

particularities of employees

Analysis of the number of people who can be recalled to work safely

Ensuring continuous, sincere communication with existing and fired workers, in a way that is

sincere, humane and empathetic

Psychological support of employees

Highlighting how the company's activities contribute to the common good and make a

difference in people's lives

Source: personal representation of Hubert Joly's vision

It will take us at probably another year until we get to the Post-Covid19 stage, but organisations are starting to evaluate it and brace themselves for it. The hypothesis proposed by Hubert Joly is that "a strong emphasis on the company's purpose can discover and unleash significant new growth". In this pandemic, organisations must understand that it is time to identify the new parts of demand to achieve their vision and mission.

The ways that corporations and their leaders choose to tackle the three stages of this pandemic and how they relate to their workers - will generate real crossroads for their workers, that will strengthen (or not) the degree of devotion of the employees and to the capacity of the corporation to prosper while exiting from the pandemic.

\section{Conclusions}

As a conclusion of the illustrated information, it can be said that leadership appears to be amongst the most researched behavioural phenomena of recent decades.

The year 2020, with its many crises, has brought even more to the fore the crucial role of leaders in sustainability and paving the way for the success of organisations. It should be emphasized that modern challenges require the implementation of leadership models that are flexible and adaptable to the environment and to challenges that are often unpredictable.

The rapid global spread of Covid-19 quickly eclipsed other recent outbreaks in size and scale. In addition to the deadly human toll and the turmoil of lives of people all over the globe, the economic damage is already great and considerable.

Faced with some challenges and a still uncertain set of risks, business leaders are rightly concerned about how their businesses will be affected and what to do next. The article presents some steps that can be made now, based on the lessons from the history of similar crisis.

It is important to take into account that companies are in different phases of dealing with the outbreak, and therefore, the impacts vary by geography and by business sector. But regardless of the extent of the virus's impact on an organization, there are fundamental qualities of resilient leadership that distinguish successful CEOs as they guide their organisations through the Covid-19 crisis.

As part of these grand imperatives, resilient leaders can take specific tactical actions to elevate these qualities during the current pandemic, mitigating its impact and helping their organisations grow stronger. With the right approach, this crisis can become an opportunity to move forward and generate even more value and positive impact on the society, rather than just bouncing back to the initial state.

\section{References}

1. Ashkenas, R., Ulrich, D., Jick, T., Kerr, S. (2002), The boundaryless organization: Breaking the chains of organizational structure. San Francisco, Jossey-Bass.

2. Bass, B. M. (1990), Bass, Stogdill's handbook of leadership: theory, research, and managerial applications (3rd ed.), New York Free Press, London, Collier Macmillan.

3. Bass, B. M. (2008), Globalization and cross national effects. Included in B. M. Bass, R. Bass (Eds.), The Bass handbook of leadership: Theory, research, and managerial applications, New York, NY: Free Press, pp. 980-1048.

4. Beechler, S., Javidan, M. (2007), Leading with a global mindset. Included in M. Javidan, R. M. Steers, M. A. Hitt (Eds.), The global mindset: Advances in international management, vol. 19, Oxford: Elsevier, pp. 131-170.

5. Black, J. S., Mendenhall, M. (1990), Cross-cultural training effectiveness: A review and a theoretical framework for future research. Academy 
of Management Review, Vol. 15(1), pp. 113-136.

6. Boal, K. B., Hooijberg, R. (2000), Strategic leadership research: Moving on. The Leadership Quarterly, Vol. 11, pp. 515-549.

7. Bond, M. H. (1988), Finding universal dimensions of individual variation in multicultural studies of values: The Rokeach and Chinese value surveys. Journal of Personality and Social Psychology, Vol. 55, pp. 1009-1015.

8. Brown, B., (2012), Daring Greatly, How the Courage to Be Vulnerable Transforms the Way We Live, Love, Parent, and Lead, New York: Gotham Books

9. Chen, C. C., Van Velsor, E. (1996), New directions for research and practice in diversity leadership. Leadership Quarterly, Vol. 7(2), pp. 285302.

10. Chhokar, J. S., Brodbeck, F. C., House, R. J. (2007), Culture and leadership around the world: The GLOBE book of in-depth studies of 25 societies. Mahwah, LEA Publishers, New Jersey

11. Dansereau, F., Yammarino, F. J. (2006), Is more discussion about levels of analysis really necessary? When is such discussion sufficient? The Leadership Quarterly, Vol. 16, pp. 879-919.

12. DeRue, D. S., Ashford, S. J. (2010), Who will lead and who will follow? A social process of leadership identity construction in organizations. Academy of Management Review, Vol. 35, pp. 627-647.

13. Dickson, M. W., Den Hartog, D. N., Mitchelson, J. K. (2003), Research on leadership in a cross-cultural context: Making progress, and raising new questions. The Leadership Quarterly, Vol. 14, pp. 729-768.

14. Dorfman, P. W. (1996), International and cross cultural leadership research. Included in B. J. Punnett, O. Shenkar (Eds.), Handbook for international management research, Ann Arbor: University of Michigan Press, pp. 267-349.

15. Dorfman, P. W. (2004), International and cross cultural leadership research. Included in B. J. Punnett, O. Shenkar (Eds.), Handbook for international management research, Ann Arbor: University of Michigan Press, pp. 265-355.

16. Dorfman, P. W., Hanges, P. J., Brodbeck, F. C. (2004), Leadership and cultural variation. Included in R. J. House, P. J. Hanges, M. Javidan, P. Dorfman, V. Gupta, Culture, leadership, and organizations: The GLOBE study of 62 societies, Thousand Oaks, Sage Publications, p. 699.

17. Drath, W. H., McCauley, C. D., Palus, C. J., Van Velsor, E., O'Connor, P. M. G., McGuire, J. B. (2008), Direction, alignment, commitment: Toward a more integrative ontology of leadership. Leadership Quarterly, Vol. 19(6), pp. 635-653.

18. Eagly, A., Chin, J. L. (2010), Diversity and leadership in a changing world. American Psychologist, Vol. 65(3), pp. 216-224.

19. Ernst, C., Chrobot-Mason, D. (2011), Boundary spanning leadership: Six practices for solving problems, driving innovation and transforming organizations. New York, McGraw-Hill.

20. Gelfand, M. J., Raver, J. L., Nishii, L., Leslie, L. M., Lun, J., Lim, B. C. (2011), Differences between tight and loose cultures: A 33-nation study, Science, Vol. 332, pp. 1100-1104.

21. Graetz, F., Smith, A. C. T. (2009), Changing forms of organizing in Australian public companies. Asia Pacific Journal of Human Resources, Vol. 47(3), pp. 340-360.

22. Gupta, A. K., Govindarajan, V. (2002), Cultivating a global mindset. The Academy of Management Executive, Vol. 16(1), pp. 116-126.

23. Hal Gregersen, Bursting the CEO Bubble, https://hbr.org/2017/03/bursting-the-ceo-bubble

24. Hanges, P. J., Dickson, M. W. (2006), Agitation over aggregation: Clarifying the development of and the nature of the GLOBE scales. The Leadership Quarterly, Vol. 17, pp. 522-536.

25. Hickson, D. J., Hinings, C. R., McMillan, C. J., Schwitter, J. P. (1974), The culture-free context of organisation structure: A tri-national comparison. Sociology, Vol. 8, pp. 59-80.

26. Hofstede, G. (1980), Culture's consequences: International differences in work-related values. Beverly Hills, Sage Publications

27. Hofstede, G. (1984), Culture's consequences: International differences in work-related values. Newbury Park, Sage Publications.

28. Hofstede, G. (2001), Culture's consequences: Comparing values, behaviors, institutions, and organizations across nations, Thousand Oaks, Sage Publications, p. 525

29. House, R. J., Hanges, P. J., Javidan, M., Dorfman, P. W., Gupta, V. (2004), Culture, leadership, and organizations: The GLOBE study of 62 societies. Thousand Oaks, Sage Publications.

30. House, R. J., Sulley de Luque, M., Dorfman, P. W., Javidan, M., Hanges, P. J. (2014), Strategic leadership: The GLOBE study of CEO effectiveness across cultures. Thousand Oaks, Sage Publications.

31. House, R. J., Wright, N., Aditya, R. A. (1997), Cross-cultural research on organizational leadership: A critical analysis and a proposed theory, In P. C. Earley, M. Erez (Eds.), New perspectives on international Industrial/Organizational Psychology San Francisco, New Lexington Press, p. 548

32. Javidan, M., Stahl, G. K., Brodbeck F., Wilderom, C. P. M. (2005), Cross-border transfer of knowledge: Cultural lessons from project GLOBE. The Academy of Management Executive, Vol. 19(2), pp. 59-76.

33. Javidan, M., Teagarden, M. B. (2011), Conceptualizing and measuring global mindset. Included in W. H. Mobley, M. Li, Y. Wang, Y., Advances in global leadership, vol. 6, Bingley, UK, Emerald Group Publishing, pp. 13-39.

34. Kogut, B., Singh, H. (1988), The effect of national culture on the choice of entry mode. Journal of International Business Studies, Vol.19(3), pp. 411-432.

35. Leong, L. Y. C., Fischer, R. (2011), Is transformational leadership universal? A meta-analytical investigation of multifactor leadership questionnaire means across cultures. Journal of Leadership, Organizational Studies, Vol. 18(2), pp. 164-174.

36. Levy, O. (2005), The influence of top management team attention patterns on global strategic posture of firms. Journal of Organizational Behavior, Vol. 26(7), pp. 797-819.

37. Levy, O., Bechler, S., Taylor, S., Boyacigiller, N. (2007), What we talk about when we talk about "global mindset": Managerial cognition in multinational corporations. Journal of International Business Studies, Vol. 38(2), pp. 231-258.

38. Lord, R. G., Maher, K. J. (1991), Leadership and information processing: Linking perceptions and organizational performance. New York, Routledge Chapman Hall.

39. Magnuson, P., Wilson R. T., Zdravkovic, S., Zhou, J. X., Westjohn, S. A. (2008), Breaking through the cultural clutter: A comparative assessment of multiple cultural and institutional frameworks, International Marketing Review, Vol. 25(2), pp. 183-201.

40. McCauley, C. D. (2010), Concepts of leadership, In E. Biech (Ed.), The ASTD leadership handbook Alexandria, VA, ASTD Press, pp. 1-11

41. McCauley, C. D., Van Velsor, E., Ruderman, M. N. (2010), Our view of leadership development. Includd in E. Van Velsor, C. D. McCauley, M. N. Ruderman (Eds.), The Center for Creative Leadership handbook of leadership development (3rd ed), San Francisco, Jossey-Bass.

42. McClelland, D. C. (1985), How motives, skills, and values determine what people do. American Psychologist, Vol. 40(7), pp. 812-825.

43. Northouse, P. G. (2001), Leadership: theory and practice (2nd ed.), Thousand Oaks, Sage Publications.

44. Pearce, C. L., Conger, J. A. (2003), All those years ago: The historical underpinnings of shared leadership. In C. L. Pearce, J. A. Conger (Eds.), Shared leadership: Reframing the hows and whys of leadership, Thousand Oaks, Sage Publications, pp. 2-18.

45. Peterson, M. F., Castro, S. L. (2006), Measurement metrics at aggregate levels of analysis: Implications for organization culture research and the GLOBE project, The Leadership Quarterly, Vol. 17, pp. 506-521.

46. Robbins, S. P. (2001), Organizational behavior (9th ed.), Upper Saddle River, N.J.: Prentice Hall, p. 314

47. Ronen, S., Shenkar, O. (1985), Clustering countries on attitudinal dimensions: A review and synthesis. Academy of Management Review, Vol. 10(3), pp. 435-454.

48. Ruderman, M, Brodbeck, F. C., Eckert, R., Gentry, B., Braddy, P. (2011), The role of fit in understanding leadereffectiveness across cultures. 
Presented at Society of Industrial and Organizational Psychology (SIOP), Chicago, April 12-14 2011.

49. Schyns, B., Kiefer, T., Kerschreiter, R., Tymon, A. (2011), Teaching implicit leadership theories to develop leaders and leadership: How and why it can make a difference. Academy of Management Learning, Education, Vol. 10(3), pp. 397-408.

50. Smith, P. B., Peterson, M. F. (1988), Leadership, organizations and culture: An event management model. Thousand Oaks, Sage Publications.

51. Smith, P. B., Dugan, S. and Trompenaars, F. (1996), National culture and the values of organizational employees. Journal of Cross-Cultural Psychology, Vol. 27(2), pp. 231-264.

52. Smith, P. B., Wang, Z. M., Leung, K. (1997), Leadership, decision-making and cultural context: Event management within Chinese joint ventures. The Leadership Quarterly, Vol. 8(4), pp. 413-431.

53. Spreitzer, G. M., McCall M. W., Mahoney J. D. (1997), Early identification of international executive potential, Journal of Aplied Psychology, Vol. 82, pp. 6-29.

54. Stogdill, R. M. (1974), Handbook of leadership: a survey of theory and research, New York: Free Press

55. Taras, V., Kirkman, B. L., Steel, P. (2010), Examining the impact of culture's consequences: A three-decade, multilevel, meta-analytic review of Hofstede's cultural value dimensions. Journal of Aplied Psychology, Vol. 95(3), pp. 405-439.

56. Tosi, H. L., Rizzo, J. R., Carroll, S. J. (1994), Managing organizational behavior (3rd ed.), Oxford, UK: Blackwell

57. Triandis, H. C. (1995), Individualism and collectivism. Boulder, Westview Press.

58. Triandis, H. C. (2004), Foreword. Included in R. J. House, P. J. Hanges, M. Javidan, P. W. Dorfman, V. Gupta, Culture, leadership, and organizations, The GLOBE study of 62 societies, $p . x v$, Thousand Oaks, Sage Publications.

59. Yukl, G. A. (2006), Leadership in Organizations (6th ed.), Upper Saddle River, Pearson Education

60. https://globeproject.com/results?page id=country\#country accessed July 2020

61. https://hbr.org/2020/05/lead-your-team-into-a-post-pandemic-world accessed July 2020

62. https://globeproject.com/study 2014 accessed July 2020 